\title{
The LLNL Accelerator Mass Spectrometry System for Biochemical ${ }^{14} \mathrm{C}$-Measurements
}

\author{
T.J. Ognibene, G. Bench, T.A. Brown, and J.S. Vogel
}

This article was submitted to the $9^{\text {th }}$ International Conference on Accelerator Mass Spectrometry, Nagoya, Japan, September 9-13, 2002

\section{October 31, 2002}




\section{DISCLAIMER}

This document was prepared as an account of work sponsored by an agency of the United States Government. Neither the United States Government nor the University of California nor any of their employees, makes any warranty, express or implied, or assumes any legal liability or responsibility for the accuracy, completeness, or usefulness of any information, apparatus, product, or process disclosed, or represents that its use would not infringe privately owned rights. Reference herein to any specific commercial product, process, or service by trade name, trademark, manufacturer, or otherwise, does not necessarily constitute or imply its endorsement, recommendation, or favoring by the United States Government or the University of California. The views and opinions of authors expressed herein do not necessarily state or reflect those of the United States Government or the University of California, and shall not be used for advertising or product endorsement purposes.

This is a preprint of a paper intended for publication in a journal or proceedings. Since changes may be made before publication, this preprint is made available with the understanding that it will not be cited or reproduced without the permission of the author.

This report has been reproduced directly from the best available copy.

Available electronically at http://www.doc.gov/bridge

Available for a processing fee to U.S. Department of Energy

And its contractors in paper from

U.S. Department of Energy

Office of Scientific and Technical Information

P.O. Box 62

Oak Ridge, TN 37831-0062

Telephone: (865) 576-8401

Facsimile: (865) 576-5728

E-mail: reports@adonis.osti.gov

Available for the sale to the public from

U.S. Department of Commerce

National Technical Information Service

5285 Port Royal Road

Springfield, VA 22161

Telephone: (800) 553-6847

Facsimile: (703) 605-6900

E-mail: orders@ntis.fedworld.gov

Online ordering: http://www.ntis.gov/ordering.htm

\section{OR}

Lawrence Livermore National Laboratory

Technical Information Department's Digital Library

http://www.llnl.gov/tid/Library.html 


\title{
The LLNL accelerator mass spectrometry system for biochemical ${ }^{14} \mathrm{C}$-measurements
}

\author{
T. J. Ognibene*, G. Bench, T. A. Brown and J. S. Vogel \\ Center for Accelerator Mass Spectrometry, Lawrence Livermore National Laboratory, L- \\ 397, 7000 East Ave., Livermore, CA 94550 USA
}

\begin{abstract}
We report on recent improvements made to our $1 \mathrm{MV}$ accelerator mass spectrometry system that is dedicated to ${ }^{14} \mathrm{C}$ quantification of biochemical samples. Increased vacuum pumping capacity near the high voltage terminal has resulted in a 2-fold reduction of system backgrounds to 0.04 amol ${ }^{14} \mathrm{C} / \mathrm{mg}$ carbon. Carbon ion transmission through the accelerator has also improved a few percent. We have also developed tritium measurement capability on this spectrometer. The ${ }^{3} \mathrm{H} /{ }^{1} \mathrm{H}$ isotopic ratio of a milligram-sized processed tap water sample has been measured at $4 \pm 1 \times 10^{-16}(430 \pm 110 \mu \mathrm{Bq} / \mathrm{mg} \mathrm{H})$. Measurement throughput for a typical biochemical ${ }^{3} \mathrm{H}$ sample is estimated to be $\sim 10$ minutes/sample.
\end{abstract}

PACS: $07.81 ;$ 41.75.A, C; 29.27.A; 32.10.B

Keywords: accelerator mass spectrometry, biochemical ${ }^{14} \mathrm{C}$ quantification, tritium, charged-particle beams

\section{Name and address for proofs:}

Ted Ognibene

L-397

Lawrence Livermore National Laboratory 
Livermore, CA 94551, USA

\section{Phone, Fax, email:}

(925) 424-6266 (voice)

(925) 423-7884 (fax)

ognibene@1lnl.gov

\section{Introduction}

Accelerator mass spectrometry (AMS) has been used in the biosciences to provide highly sensitive and precise ${ }^{14} \mathrm{C}$ quantification at environmentally relevant doses[1-5]. The development of lower acceleration voltages [6,7] for detection of specific isotopes leads to the possibility of spectrometers tailored to particular AMS applications. In the biosciences, precision can be relaxed to enable high sample measurement throughput. High sensitivity, however, must be maintained to allow for the measurement of very small samples. Specifically, we require for the measurement of at least 300 samples per day containing $1 \mathrm{mg}$ or less carbon, at 3-5\% precision with reproducible background count rates equivalent to $<1$ attomole ${ }^{14} \mathrm{C} / \mathrm{mg}$ carbon.

Tritium is also a widely used isotope tracer in biochemical experiments. Many compounds that cannot be easily synthesized with a ${ }^{14} \mathrm{C}$ label can be tagged with ${ }^{3} \mathrm{H}$. AMS provides a factor of 1000 improvement in tritium sensitivity on milligram-sized samples with much higher throughput over traditional decay measurement techniques[8].

We recently reported on the characterization of a 1 MV AMS spectrometer constructed at the Lawrence Livermore National Laboratory's Center for Accelerator Mass 
Spectrometry which is dedicated to biochemical ${ }^{14} \mathrm{C}$ measurements[9]. This spectrometer meets or exceeds our requirements as outlined above. This paper describes the improvements we have recently made to our spectrometer in the measurement of ${ }^{14} \mathrm{C}$ and shows some initial results in the development of ${ }^{3} \mathrm{H}$ measurement capability at $<1 \mathrm{MV}$.

\section{Experimental}

A photograph of the spectrometer is shown in Fig. 1. A copy of the LLNL high-output cesium-sputter source is used to generate negative ions from solid targets[10]. After energy and momentum analysis, ions are injected into the high voltage terminal of a National Electrostatic Corporation 3SDH-1 1MV Pelletron® tandem accelerator. Chargeexchange and molecular ion dissociation processes occur in a long cell, filled with diffuse argon gas located at the center of the accelerator. After subsequent acceleration, transmitted ions are then momentum-analyzed followed by an energy-analysis before impinging on a silicon surface barrier detector. The spectrometer is housed in a $44 \mathrm{~m}^{2}$ room adjacent to and is $\sim 20 \%$ the size of the LLNL 10MV FN tandem accelerator[11]. Details of the spectrometer are provided elsewhere[9,12].

Recently, we replaced the thermocouple ion pressure gauge to provide for a more stable and consistent monitor of the argon gas density within the stripper canal. We added a second $2201 / \mathrm{sec}$ turbomolecular vacuum pump to the beam line region between the high voltage terminal of the accelerator and the analysis magnet. We also placed a collimator at the entrance to the analysis magnet to limit the amount of residual argon gas reaching the magnetic field region of the magnet. Additionally, we replaced the beam profile monitor located in this region with an insertable Faraday cup. 
These changes necessitated the recharacterization of the spectrometer to maximize sample throughput and precision and to minimize backgrounds. This work required that the gas pressure within the stripper canal be adjusted while observing the count rate within the ${ }^{14} \mathrm{C}$ gate of the detector. For a ${ }^{14} \mathrm{C}$-free carbonaceous sample, this lowest count rate ultimately determines the sensitivity of the spectrometer. The gas pressure required to reach this limit also determines the effective transmission through the accelerator given that the most efficient coupling of the ion source to the accelerator has been achieved.

While the spectrometer was originally designed to quantitate ${ }^{14} \mathrm{C}$, we have begun to explore ${ }^{3} \mathrm{H}$ measurement capabilities. Solid $\mathrm{TiH}_{2}$ targets for ${ }^{3} \mathrm{H}$-AMS measurement were prepared from 1-10 $\mu \mathrm{l}$ liquid water samples[13]. The large relative mass difference between hydrogen and tritium precludes us from using electrostatic isotope switching for ions with energy $>15 \mathrm{keV}$. The ion source is designed to extract ions at $40 \mathrm{kV}$ and operation at potentials significantly less than is inefficient. Instead, the magnetic field of the injection magnet is cycled to permit the sequential transmission of the two $40 \mathrm{keV}$ isotopes. Tritium is measured for 10 seconds with the silicon surface barrier detector located at the end to the spectrometer while hydrogen is measured for 5 seconds at an offaxis Faraday cup located at the entrance to the accelerator. Changing the magnetic field requires approximately 20 seconds.

\section{Results and discussion}

Fig. 2 shows a plot of carbon isotope ratios measured at different argon gas pressures for graphitized coal samples. In this spectrum, all events falling within the appropriate hardware and software gates are recorded as ${ }^{14} \mathrm{C}^{+}$. Each data point represents an average of 
at least 3 measurements of 3 different samples with the error bars indicating the 1-sigma standard deviation about the mean. The average background between 41 and 47 mTorr is 0.0041 Modern (0.40 attomoles ${ }^{14} \mathrm{C} / \mathrm{mg}$ carbon). As the gas pressure increases, ion scattering in the gas canal and beam line tubes increases, which results in the higher background levels observed in the detector. No attempt was made to differentiate sources contributing to detector signal when tuned to ${ }^{14} \mathrm{C}$. Similarly-prepared coal samples are $<0.002$ Modern when measured on the $10 \mathrm{MV}$ FN tandem, indicating that about $1 / 2$ of the counts are still scattered ions or contaminants.

This level in system background represents a factor of two improvement in sensitivity from earlier work[9]. Also, about 10 mTorr less gas pressure is required to adequately destroy interfering molecules. It is possible that the argon gas is better constrained within the beam line by the additional vaccum pump and limiting aperture. This allows for the molecules to be dissociated in a shorter path, thus limiting ion scattering. We have seen an increase in the carbon ion transmission through the accelerator to approximately $36 \%$.

Fig. 3 shows a comparison of hydrogen isotope ratios of tritium standards measured by AMS from that determined from LSC. The error bars represent the 1-sigma standard deviation about the average of at least three measurements of two replicate samples in the AMS case and three measurements of a single standard in the LSC case. From a calibration curve generated from the data, the isotope ratio of a processed tap water blank was determined to be $4 \pm 1 \times 10^{-16}{ }^{3} \mathrm{H} /{ }^{1} \mathrm{H}\left(430 \pm 110 \mu \mathrm{Bq}{ }^{3} \mathrm{H} / \mathrm{mg} \mathrm{H}\right)$.

Sample throughput of a typical $1 \mathrm{mg}$-sized biomedical sample with a $10^{-14} \mathrm{~T} / \mathrm{H}$ ratio is estimated to be 10 minutes/sample based on observed ${ }^{1} \mathrm{H}^{-}$ion currents of $150 \mu \mathrm{A}$. This is 
to obtain 5\% precision based on counting statistics with at least 3 replicate measurements. A similarly-sized sample would require more than 10 hours of decay counting to obtain this precision in the counting statistics of a single measurement, assuming no background and $100 \%$ detection efficiency. Tandem accelerating voltage and Ar stripper gas pressure were set to $520 \mathrm{kV}$ and $45 \mathrm{mTorr}$, which is identical to that used for the quantitation of carbon isotope ratios. Further work is continuing to ascertain if these are the preferred operating parameters for hydrogen isotope ratio quantitation.

\section{Conclusions}

Routine operation of the spectrometer for biochemical ${ }^{14} \mathrm{C}$ measurements began in April 2001. On average, 650 samples are measured each month in a 2-3 days per week operation. Table 1 summarizes the performance and operation of the spectrometer. Tritium quantitation development, as well as other AMS measurement techniques are conducted while the spectrometer is not busy with routine measurements.

\section{Acknowledgements}

This work was performed under the auspices of the U.S. Department of Energy by University of California Lawrence Livermore National Laboratory under contract No. W7405-Eng-48 and under the National Center for Research Resources Grant \# RR13461.

\section{References}

[1] S.P.H.T. Freeman and J.S. Vogel, Int. J. Mass Spectrom. 143 (1995) 247. 
[2] T.J. Ognibene, M.L. Roberts, J.R. Southon and J.S. Vogel, in Synthesis and Applications of Isotopically Labelled Compounds, Vol. 7, U. Pleiss and R. Voges, eds., John Wiley \& Sons, Chichester, UK (2001) 515.

[3] J.S. Vogel and K.W. Turteltaub, in Advances in Experimental Medicine and Biology, A.J. Clifford and H-G. Müller . eds., Plenum, New York (1998) 397.

[4] K.W. Turteltaub and J.S. Vogel, Curr. Pharm. Des. 6 (2000) 991.

[5] M. Miyahita, J.M. Presley, B.A. Buchholz, K.S. Lam, Y.M. Lee, J.S. Vogel, B.D. Hammock, Proc. Nat. Acad. Sci., 98 (2001) 4403.

[6] H.W. Lee, A. Galindo-Uribarri, K.H. Chang, L.R. Kilius, T.E. Litherland, Nucl. Instr. Meth. B 5 (1984) 208.

[7] M. Suter, St. Jacob, H.A. Synal, Nucl. Instr. Meth. B 123 (1997) 148.

[8] K.H. Dingley, M.L. Roberts, C.A. Velsko and K.W. Turteltaub, Chem. Res. Toxicol. $11(1998) 1217$.

[9] T.J. Ognibene, G. Bench, T.A. Brown, G.F. Peaslee and J.S. Vogel, Int. J. Mass Spectrom. 218 (2002) 255.

[10] J.R. Southon, M.L. Roberts, Nucl. Instr. Meth. B 172 (2000) 257.

[11] M.L. Roberts, G.S. Bench, T.A. Brown, M.W. Caffee, R.C. Finkel, S.P.H.T. Freeman, L.J. Hainsworth, M. Kashgarian, J.E. McAninch, I.D. Proctor, J.S. Southon, J.S. Vogel, Nucl. Instr. Meth. B 123 (1997) 57.

[12] T.J. Ognibene, T.A. Brown, J.P. Knezovich, M.L. Roberts, J.R. Southon, J.S. Vogel, Nucl. Instr. Meth. B 172 (2000) 47. 
[13] M.L. Chiarappa-Zucca, K.H. Dingley, M.L. Roberts, C.A. Velsko and A.H. Love, Anal. Chem. (in press). 


\section{Figure Captions}

Fig. 1. Photograph of the LLNL AMS system for biochemical ${ }^{14} \mathrm{C}$ measurements.

Fig. 2. Carbon isotope ratios measured as a function of argon gas pressure in the molecular dissociation cell. Tandem accelerating voltage of $520 \mathrm{kV}$ was applied during these tests. Error bars, when not shown, are smaller than the data point.

Fig. 3. Tritium standard curve with the AMS measured hydrogen isotope ratio as the abscissa and the LSC-determined ratio as the ordinate. 


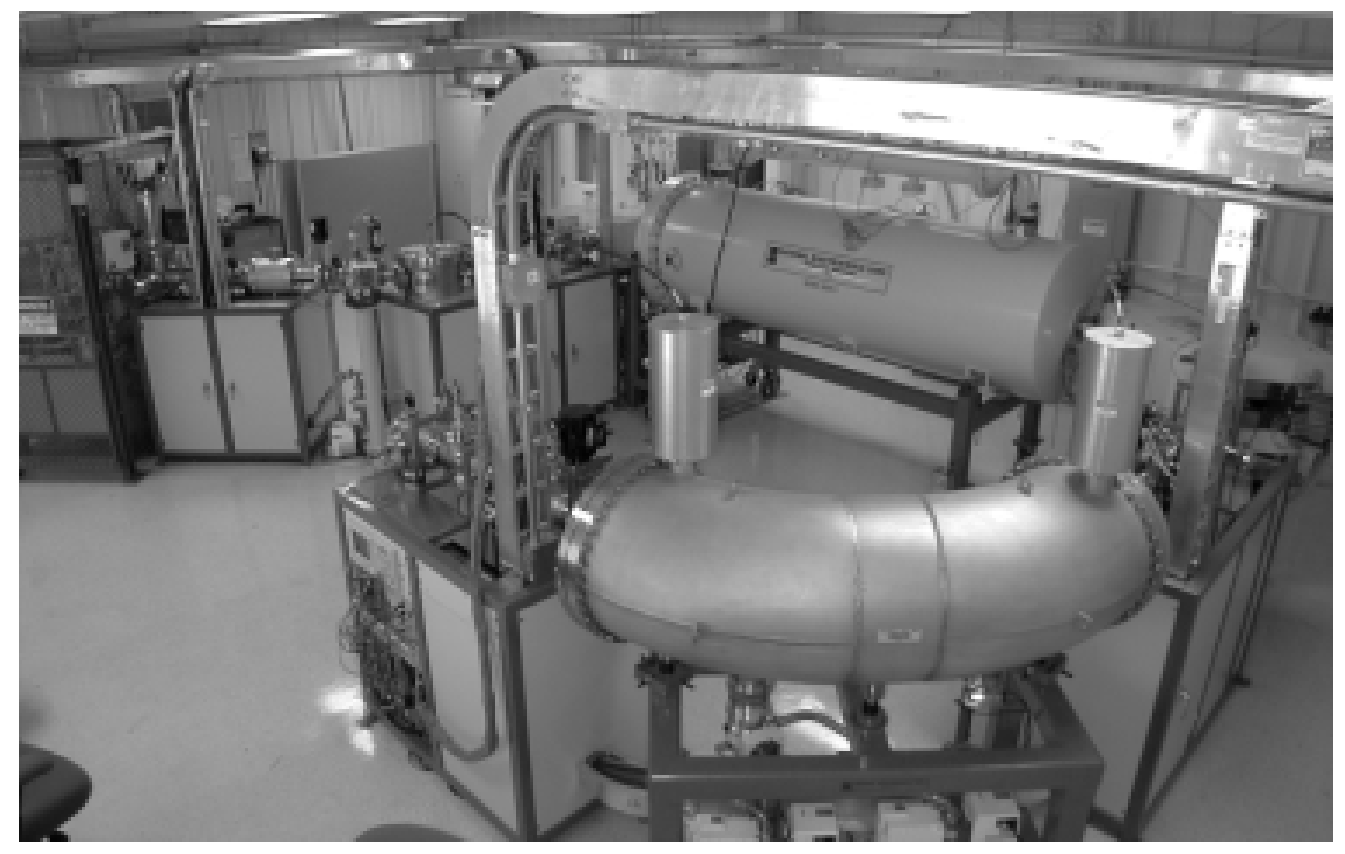

Figure 1 


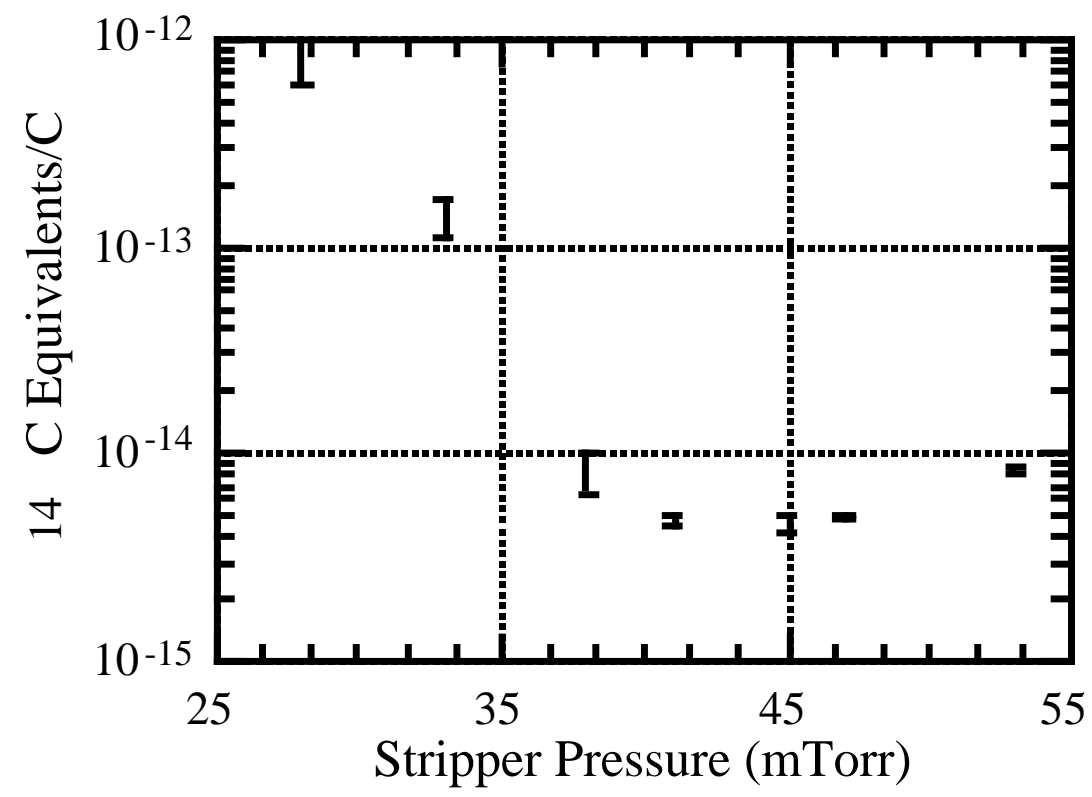

Figure 2 


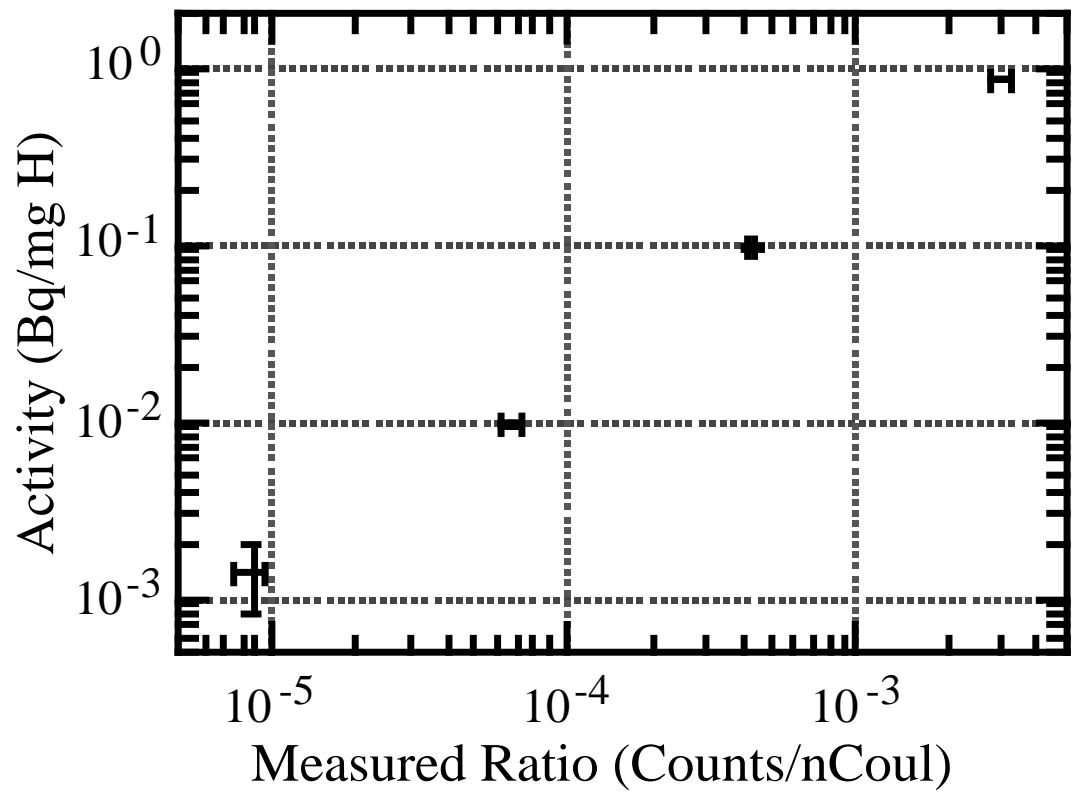

Figure 3 
Table 1.

Summary performance and operating parameters for the 1-MV spectrometer for the measurement of ${ }^{14} \mathrm{C}$.

\begin{tabular}{ll}
\hline Sample Performance & \\
Sensitivity & 0.004 Modern \\
& $\left(0.4\right.$ amol ${ }^{14} \mathrm{C} / \mathrm{mg}$ carbon $)$ \\
Dynamic range & $4-5$ orders of magnitude \\
Sample throughput & 105 samples $/ 8 \mathrm{~h}$ (average) \\
Precision & $3 \%$ \\
& \\
Operation & \\
Ion source & 64 sample cesium sputter \\
Extraction voltage & $40 \mathrm{kV}$ \\
Source output & $300 \mu \mathrm{A}$ (typical) \\
Analyzed low-energy ions & $12 \mathrm{C}^{-}(200 \mu \mathrm{A}$ typical) \\
Accelerator voltage & $520 \mathrm{kV}$ \\
Ion stripping gas pressure & $\sim 45 \mathrm{mTorr}$ argon \\
Analyzed stable ions & $1.08 \mathrm{MeV}{ }^{13} \mathrm{C}^{+}$ \\
& $(800 \mathrm{nA} \mathrm{typical)}$ \\
Analyzed rare ions & $1.08 \mathrm{MeV}{ }^{14} \mathrm{C}^{+}$ \\
\hline
\end{tabular}

